\section{Call for a cull of pointlessly different reference styles}

SIR - Coping with the multitude of formats imposed by academic journals for citing references to the literature is an aggravating and labour-intensive experience. Some of this staggering profusion of styles can be reasonably rationalized, for example the financial imperatives for saving space. But, as editor-in-chief of DNA Repair, I find that my discussions with the managing editors and publishers of several prominent scientific journals reveal little else by way of rational decisions.

What difference can it possibly make if an author's initials are placed before or after his/ her surname, or where exactly in the citation the date of a publication is situated - not to mention the myriad variations of required fonts, italics, colons, commas and full stops? And does it really make a material difference whether references are arranged by author name (alphabetically or not) or numerically, and are identified in the text by number (which may be required in superscript or not) or by author name(s)?

The prevailing attitude seems to be that we are irrevocably stuck with this state of affairs and that trying to obtain consensus among editors and publishers to adopt a universal format would be like herding mosquitoes.

This letter is by way of an appeal to the publishers and editors of major scientific periodicals to agree on a single-standard reference format. Such an initiative would, I hope, go a long way to cajoling the remaining mosquitoes to join the herd. Exactly what this format should be is outside the province of this missive. But I doubt if many would disagree that a useful and sensible method would be to list references in alphabetical order, including only the first three author names, the entire article title, the journal name, the volume number, the first page number, and the publication year.

In recent years, computer programs have been designed to facilitate the management of varying reference styles. However, these are far from perfect, and I am informed by one prominent journal that staff members are routinely obliged to correct these in order to ensure conformity to the journal's required style. Furthermore, some of these programs use a series of macros that can interfere with the typesetting programs used by publishers.

With the advent of electronic publishing, additional problems have surfaced. $\mathrm{A}$ consortium representing many of the leading academic publishers has established an electronic artid-linking system in which articles are assigned a unique and irrevocable digital object identifier (doi). The doi consists of a unique alpha-numeric character string that is assigned to an article by the publisher at the time of electronic publishing. Aside from the fact that there is no uniform style for citing a doi, many identifiers do not even clearly identify the journal of origin.

I find it nothing short of pathetic that the scientific community has endured this seemingly arbitrary imposition for so long! Errol C. Friedberg

Department of Pathology, University of Texas Southwestern Medical Center at Dallas, Dallas, Texas 75390-9072, USA

\section{Noting Croats' difference from other Slavs isn't racist}

SIR — I am not among those who think that Dragan Primorac is a great minister of science and education, and I may have my doubts about how good a scientist he is. But your News story " Race claims spark fury over Croatia's school curriculum" (Nature 437, $463 ; 2005$ ) builds on tensions in this case in an unhelpful way. As a Croat, I could just as easily accept Croats being Slavs as I could their being ethnically distinct.

There is nothing racist in Primorac's claim that one genetic marker differentiates Croats from other Slavs. To call it ${ }^{\alpha}$ potentially incendiary in the Balkan region, recently torn apart by civil war" does nothing but provoke bad feeling. As a Croat and, more importantly, as a scientist, I am eager to know whether Primorac's theory is correct or not. But I will reserve judgment until there is an evidence-based scientific explanation of his interpretation of the Science paper, as quoted in your News story.

After all, Primorac is quoted as saying "We need much more scientific evidence before we draw conclusions", and the coordinator of the school curriculum says that examples such as this would not be included in textbooks. So I am wondering about who is actually furious, and why and most importantly, what is the scientific rationale for being furious?

Ognjen Çuliç

Medvedgradska 70, 10000 Zagreb, Croatia

\section{Internet forest-watchers a new force for conservation}

SIR - Your News in Brief story "Enthusiast uses Google to reveal Roman ruins" (Nature 437,$307 ; 2005$ ) made me wonder whether the time for a new conservationism is not already on the horizon. A time when the convergence of imaging and grid computing technologies, together with a policy of free access to catalogues of high-resolution Earth imagery, will make it possible to monitor selected patches of forest across the globe using the Internet.
Indeed, new instruments such as the widefield imager to be launched with the third Chinese-Brazilian Earth Resources Satellite in 2008 , with a spatial resolution of 70 metres and a revisiting time of less than a week, are ideally configured for this task.

This resource will be free of charge to users in Brazil and could be in other parts of the world too, depending on agreements with their governments. Meanwhile, a lowerresolution resource, MODIS, is already available at http://modis.gsfc.nasa.gov. Although rainforests are often covered by clouds, reducing the amount of time that data are available, the large numbers of potential watchers would maximize the use of data.

Today, thousands of enthusiasts are using their home computers to search for signs of extraterrestrial intelligence. Perhaps there could soon be a global network of forestwatchers, pushing the alarm button every time their protected gardens are under threat. Fernando Manuel Ramos

National Institute for Space Research (INPE), Avenida dos Astronautas 1758 ,

12227-010 Săo Josédos Campos, Sao Paulo, Brazil

\section{Later results don't confirm antidepressant suicide link}

SIR — Your News story "Adult suicides linked to popular antidepressant " (Nature 436, 1073; 2005) reports the results of an analysis concluding that the antidepressant paroxetine is associated with suicide risk in adults and should therefore be restricted, although other studies have shown no cause for concern. But a much larger analysis by the European registration authorities (EMEA) in 2004 concluded that, although suicide risk is present in children and adolescents and possibly in young adults aged $18-29$, it is not present in adults above that age (see www. emea.eu.int/pdfs/human/press/pr/ 1120604en.pdf).

The analysis cited in your News story looked at 16 studies, comprising 1,466 patients, that were part of the original registration dossier for paroxetine in 1989. Numerous randomized clinical trials have been conducted since then, though; the EMEA analysis used results from 171 randomized clinical trials, involving more than 14,000 patients, of whom about 5,000 had depression.

Although the first studies may suggest a possible elevated risk, the accumulation of evidence since then does not confirm this suggestion. Conclusions drawn from the EMEA study have been integrated into the product information for paroxetine. Tamar Wohlfarth, Jitschak Storosum Medicines Evaluation Board of The Netherlands, PO Box 16229, 2500 BE The Hague, The Netherlands 